\title{
PENGARUH BUDAYA ORGANISASI TERHADAP KINERJA KARYAWAN \\ (Studi pada Karyawan Bank BRI Kantor Cabang Cianjur)
}

\author{
Ilham Ramadhiansah ${ }^{1}$, Ika Celsie Agustin ${ }^{2}$, Hilmi Fauzi ${ }^{3}$, Hilmi Abdil Majid ${ }^{4}$, \\ Herdiansyah Nurzaini ${ }^{5}$, Babay Suhaemi ${ }^{6}$ \\ 1,2,3,4,5,6 Universitas Islam Negeri Sunan Gunung Djati Bandung \\ Email:Uinsgd@ac.id
}

\begin{abstract}
Abstrak
Penelitian ini berjudul Pengaruh Budaya Organisasi terhadap Kinerja Karyawan (Studi pada Karyawan Bank BRI Kantor Cabang Cianjur), lokasi ini dipilih oleh peneliti dengan pertimbangan bahwa Bank BRI Kantor Cabang Cianjur merupakan salah satu bank terbesar yang ada di Kabupaten Cianjur. Latar belakang penelitian ini adalah Budaya Organisasi sebagai salah satu faktor penting yang mempengaruhi Kinerja Karyawan Bank BRI Kantor Cabang Cianjur. Penelitian ini bertujuan untuk mengetahui pengaruh secara simultan dan parsial budaya organisasi terhadap kinerja karyawan. Berdasarkan hasil analisis menunjukkan bahwa budaya organisasi konstruktif, budaya organisasi pasif-defensif, dan budaya organisasi agresif-defensif berpengaruh secara simultan terhadap kinerja karyawan sebesar 53,4\% sedangkan sisanya $44,6 \%$ dipengaruhi oleh variabel lain yang tidak diteliti dalam penelitian ini. Budaya organisasi konstruktif berpengaruh secara parsial dengan nilai signifikan 0,027 lebih kecil dari $\alpha=0,056$. Budaya organisasi pasif-defensif berpengaruh secara parsial dengan nilai signifikan 0,038 lebih kecil dari $\alpha=0,055$. Budaya organisasi agresifdefensif berpengaruh secara parsial dengan nilai signifikan 0,004 lebih kecil dari $\alpha=$ 0,040. Maka diharapkan Bank BRI Kantor Cabang Cianjur untuk selalu meningkatkan dan menyempurnakan budaya organisasi demi mencapai kinerja karyawan yang maksimal.
\end{abstract}

\section{Kata Kunci: Budaya Organisasi, Kinerja Karyawan}

\begin{abstract}
This study entitled The Influence of Organization Culture to Employee Performance (Studies at Bank BRI Cianjur Branch Office), the location was choosen because Bank BRI Cianjur Branch Office is one of the biggest bank at Cianjur city. Background this research is Organization Culture which one of the important factor that can affecting the Employee Performance of Bank BRI Cianjur Branch Office. This study aims to determine simultaneously effect and partially effect of organizational culture on employee performance. The result showed that constructive organization culture, passive-defensive organization culture, and aggressive- defensive organization culture simultaneous has influence on employee performance by 53,4\% and the other $44,6 \%$ has influenced by other variables that not included in this research. Constructive organization culture is partially affected by significant value of 0,027 smaller than $\alpha=$ 0,056. Passive-defensive organization culture is partiallu affected by significant value of 0,038 smaller than $\alpha=0,055$. Aggressive-defensive organization culture is partially affected by significant value of 0,004 smaller than $\alpha=0,040$. Wishing the Bank BRI Cianjur Branch Office always increase and make perfect of this organizational culture to get maximal employee performance.
\end{abstract}

Keywords: Organization Culture, Employee Performance.

\section{A. PENDAHULUAN}


Organisasi merupakan tempat berkomunikasi pada setiap manusia dengan manusia lainnya di mana setiap manusia tersebut memiliki karakter yang berbeda-beda. Organisasi atau perusahaan menjadi wadah atau forum dari manusia-manusia tersebut untuk mencapai tujuannya dan visinya. Sebuah organisasi tentu memiliki tujuan atau visi ketika organisasi tersebut didirikan, tujuan atau visi organisasi adalah dapat dicapai jika budaya organisasi yang ada di setiap dalam organisasi bekerja dengan baik dan benar lalu ditunjang dengan kinerja dari anggotanya.

Suatu organisasi pastinya akan memiliki budaya organisasi yang berbeda-beda dari setiap organisasi lainnya. Budaya organisasi tentunya akan membawakan berbagai efek bagi Sumber Daya Manusia, sehingga tenaga kerja dari satu organisasi tersebut harus mampu Menyesuaikan dengan bijak budaya organisasi dengan baik. Budaya organisasi yang bekerja dengan baik pastinya akan meberikan dan membawa organisasi untuk mendapatkan tujuannya. Peranan budaya di dalam organisasi sangat penting, dimana budaya dapat menjadi ciri dari sebuah organisasi dan membedakannya dengan organisasi lain. dengan berjalannya masa atau waktu dan berkembangnya zaman, budaya organisasi akan menyesuaikan pula.

Perubahan budaya bisa terlihat dari sistem ideologi politik, budaya adat istiadat, dan bahasa ataupun dengan cara berpenampilan. Perubahan budaya di suatu organisasi itu memperlihatkan adanya keinginan dan tujuan yang lebih baik kedepannya. Perubahan yang terjadi tentu akan membuat budaya organisasi membentuk cara kerja baru dari tenaga kerja yang akan berpengaruh terhadap kinerja dari karyawan itu sendiri.

Kinerja adalah hal-hal yang sangat diperhitungkan bilamana organisasi atau perusahaan ingin mencapai visi atau tujuannya, organisasi yang baik tentu akan memilah dan memilih dengan bijak setiap kapasitas kemampuan Tenaga kerjanya untuk mencapai suatu kinerja yang maksimal agar dapat mencapai visi misi dari organisasi atau perusahaan itu. Kinerja diukur dengan cara yang berbeda-beda antara satu perusahaan dengan perusahaan lainya, bahkan bisa saja tolak ukur dari kinerja itu berbeda dan memberikan hasil penilaian kinerja yang berbeda-beda pula. Menurut

KBBI, kinerja adalah hasil yang dicapai dari yang telah dilakukan, dikerjakan seseorang dalam melaksanakan kerja atau tugas. Kinerja merupakan prestasi kerja atau performance, yaitu hasil kerja selama periode tertentu dibanding dengan berbagai kemungkinan. Kinerja bisa dikatakan sebagai sebuah tindakan yang dapat dilihat dan diamati serta dapat dimungkinkan untuk pencapaian tujuan. Kinerja juga dapat dikatakan sebagai kombinasi dari kemampuan, usaha, kesempatan yang dapat dinilai 
hasil kerjanya yang diperoleh dari suatu periode tertentu. Kinerja dihitung berdasarkan apa yang sudah dikerjakan dan kesesuaian antara hasil dengan tujuan organisasi.

Berdasarkan penjelasan di atas dapat kita simpulkan bahwa budaya organisasi dan kinerja karyawan merupakan hal yang tidak dapat dipisahkan dari sebuah organisasi. Budaya organisasi maupun kinerja karyawan memiliki relasi pada sebuah organisasi yang bisa mempengaruhi satu dengan yang lainnya sehingga dapat Dianalisis bagaimana hubungan dari kedua hal tersebut. Kami telah melakukan suatu penelitian di Bank Rakyat Indonesia (BRI) Cabang Cianjur. Tempat ini terpilih sebagai tempat Analisis karena persaingan bisnis perbankan pada saat ini ketat dan hebat, bank juga merupakan bidang penunjang perekonomian negara sehingga perlu untuk memperhatikan sumber daya manusia yang ada pada bisnis tersebut. BRI Cabang Cianjur tersebut mempunyai banyak Tenaga kerja hingga bisa diketahui pengaruh dari budaya organisasi terhadap kinerja karyawan.

Analisis ini dilakukan untuk mengamati bagaimana budaya organisasi dapat mempengaruhi suatu kinerja karyawan BRI Cabang Cianjur. Berdasarkan latar belakang yang telah dijelaskan, maka kami berinisiatif untuk mengangkat masalah tersebut dan membahasnya pada sebuah Jurnal Laporan praktik kerja lapangan yang berjudul "Pengaruh Budaya Organisasi Terhadap Kinerja Karyawan (Studi Kasus Pada Karyawan Bank BRI Cabang Cianjur)

Menurut Luthans dalam Susanto (2006:111), "Budaya organisasi adalah norma-norma dan nilai-nilai yang mengarahkan perilaku anggota organisasi”. Setiap anggota akan berperilaku sesuai dengan budaya yang berlaku agar diterima di lingkungannya, dengan kata lain budaya merupakan salah satu hal yang digunakan dalam keseharian anggota organisasi dan sebagai petunjuk bagaimana anggota organisasi bertingkah laku. Sedangkan menurut Sarplin dalam Susanto (2006: 120), "Budaya organisasi adalah suatu sistem nilai, kepercayaan dan kebiasaan dengan struktur formalnya untuk menghasilkan norma- norma perilaku organisasi”. Jadi budaya organisasi merupakan alat pembentuk norma yang digunakan dalam sebuah organisasi. Sondang (1995: 233), "Budaya organisasi adalah penggabungan antara gaya kepemimpinan manajemen puncak dan norma-norma serta system nilai keyakinan para anggota organisasi”. Budaya organisasi berarti sebuah bentuk yang terjadi karena adanya gaya kepemimpinan dan norma yang sudah ada di dalam organisasi yang mana setiap penggabungan gaya kepemimpinan dengan norma yang ada akan membentuk suatu budaya organisasi itu sendiri. Menurut Mulyadi (2006: 270), "Budaya organisasi adalah apa yang karyawan rasakan dan bagaimana persepsi ini menciptakan 
suatu pola teladan kepercayaan, nilai-nilai dan harapan”.

Budaya organisasi yang disebutkan oleh Kreitner dan Kinicki memiliki karakteristik yang berbeda antar setiap tipe budaya organisasi. Karakteristikkarakteristik dari tipe budaya organisasi tersebut adalah sebagai berikut:

1. Budaya konstruktif adalah budaya dimana para karyawan didorong untuk berinteraksi dengan orang lain dan mengerjakan tugas dan proyeknya dengan cara yang akan membantu mereka dalam memuaskan kebutuhannya, berhubungan dengan pencapaian tujuan aktualisasi diri, penghargaan yang manusiawi, dan persatuan.

2. Budaya pasif-defensif bercirikan keyakinan yang memungkinkan bahwa karyawan berinteraksi dengan karyawan lain dengan cara yang tidak mengancam keamanan kerjanya sendiri. Budaya ini mendorong keyakinan normatif yang berhubungan dengan persetujuan, konvensional, ketergantungan, dan penghindaran.

3. Perusahaan dengan budaya agresif-defensif mendorong karyawannya untuk mengerjakan tugasnya dengan keras untuk melindungi keamanan kerja dan status mereka. Tipe budaya ini lebih bercirikan keyakinan normatif yang mencerminkan oposisi, kekuasaan dan kompetitif.

Perusahaan tentu memiliki indikator-indikator tertentu untuk menilai dan mengukur kinerja karyawannya. Menurut Robbins(2006:260) menyebutkan ada lima indikator untuk mengukur kinerja karyawan sebagai berikut:

1. Kualitas

Kualitas kerja karyawan diukur dari persepsi kapasitas dia bekerja dalam perusahaan tersebut atau dalam organisasi perusahaan tersebut teruatama dalam Psikomotorik karyawan.

2. Kuantitas

Merupakan jumlah kapasitas berbentuk unit pada kegiatan karyawan dalam hitungan numerical.

3. Ketepatan waktu

Kedisiplinan dalam mengehargai waktu pada suatu pekerjaan yang bersifat deadline atau dalam janka waktu yang harus diselesaikan, Dan menjadi tolak ukur dalam menentukan kebijaksanaan karyawan.

4. Efektivitas

Merupakan daya guna pada Satuan Logistik maupun manusia dalam 
menggunakan daya yang telah disesuaikan dengan batasan batasan tertentu.

5. Kemandirian

Yaitu bentuk komitmen kerja yang nantinya menjadikan karyawan memiliki nilai dam moral kerja tinggi dengan diiringi loyalitas pada perusahaan atau organisasi

$\mathrm{H}_{1}$ : Budaya organisasi konstruktif berpengaruh secara signifikan terhadap kinerja karyawan

$\mathrm{H}_{2}$ : Budaya organisasi pasif - defensif berpengaruh secara signifikan terhadap kinerja karyawan

$\mathrm{H}_{3}$ : Budaya organisasi agresif - defensif berpengaruh secara signifikan terhadap kinerja karyawan

$\mathrm{H}_{4}$ : Budaya organisasi konstruktif, budaya organisasi pasif - defensif dan budaya organisasi agresif-defensif secara simultan bepengaruh signifikan terhadap kinerja karyawan

\section{B. METODE}

Penelitian ini merupakan penelitian penjelasan Atau (explanatory research) pada pendekatan kuantitatif. Penelitian dilakukan di Bank BRI Kantor Cabang Cianjur Jl. Adisucipta no.8. Diambil pada tanggal 4-27 juni dengan banyaknya penjelasan yang spesifik pada setiap 7 teori. Didapatkan sampel 78 orang responden dengan pengumpulan data menggunakan kuesioner yang diwakilkan oleh Staf atau seorang Supervisor Operasional bagian rumah tangga (SDM).

\section{HASIL DAN PEMBAHASAN}

Tabel 1. Hasil Analisis Regresi Linier Berganda

\begin{tabular}{|c|c|c|c|c|c|}
\hline \multirow{2}{*}{ Variabel Bebas } & \multicolumn{2}{|c|}{$\begin{array}{c}\text { Unstandardized } \\
\text { Coefficients }\end{array}$} & $\begin{array}{c}\text { Standardized } \\
\text { Coefficients }\end{array}$ & \multirow{2}{*}{$\mathrm{t}$} & \multirow{2}{*}{ Sig. } \\
\cline { 2 - 4 } & $\mathrm{B}$ & Std. Error & Beta & & \\
\hline (Constant) & 6.809 & 3.806 & & 1.789 & 0.080 \\
\hline $\mathrm{X} 1$ & 0.282 & 0.123 & 0.267 & 2.399 & 0.020 \\
\hline $\mathrm{X} 2$ & 0.621 & 0.287 & 0.273 & 2.138 & 0.039 \\
\hline $\mathrm{X} 3$ & 0.462 & 0.157 & 0.367 & 2.953 & 0.005 \\
\hline
\end{tabular}

Sumber : Data Primer diolah, 2020

Tabel 2. Koefisien Determinasi

\begin{tabular}{|c|c|c|}
\hline R & R Square & Adjusted R Square \\
\hline 0.755 & 0.572 & 0.545 \\
\hline
\end{tabular}

Sumber : Data Primer diolah, 2020 
Tabel 3. Uji F

\begin{tabular}{|c|c|c|c|c|c|}
\hline Model & $\begin{array}{c}\text { Sum of } \\
\text { Squares }\end{array}$ & df & $\begin{array}{c}\text { Mean } \\
\text { Square }\end{array}$ & F & Sig. \\
\hline Regression & 227.487 & 3 & 75.829 & 21.680 & 0.000 \\
\hline Residual & 171.388 & 49 & 3.598 & & \\
\hline Total & 398.869 & 52 & & & \\
\hline \multicolumn{7}{|c|}{ Sumber : Data Primer diolah, 2020 }
\end{tabular}

Tabel 4. Uji $t$

\begin{tabular}{|c|c|c|}
\hline Variabel Bebas & $\mathrm{t}$ & Sig. \\
\hline (Constant) & 1.789 & 0.080 \\
\hline $\mathrm{X} 1$ & 2.399 & 0.020 \\
\hline $\mathrm{X} 2$ & 2.138 & 0.039 \\
\hline $\mathrm{X} 3$ & 2.953 & 0.005 \\
\hline
\end{tabular}

Sumber : Data Primer diolah, 2020

\section{Variabel Budaya Organisasi Konstruktif (X1)}

Hasil pengujian hipotesis koefisien regresi variabel Budaya Organisasi Konstruktif (X1) dapat dituliskan Variabel X1 memiliki nilai t hitung sebesar 2,399 dan didapatkan nilai signifikansi sebesar 0,020. Nilai statistik uji thitung tersebut lebih besar daripada ttabel $(2,399>2,010)$ dan nilai signifikansi lebih kecil daripada $\alpha=$ 0,05. Pengujian ini menunjukkan bahwa $\mathrm{H} 0$ ditolak dan $\mathrm{H} 1$ diterima, dapat disimpulkan bahwa variabel Budaya Organisasi Konstruktif(X1) berpengaruh signifikan terhadap variabel Kinerja Karyawan (Y).

\section{Variabel Budaya Organisasi Pasif-Defensif (X2)}

Hasil pengujian hipotesis koefisien regresi variabel Budaya Organisasi PasifDefensif (X2) dapat dituliskan Variabel X2 memiliki nilai thitung sebesar 2,138 dan didapatkan nilai signifikansi sebesar 0,039. Nilai statistik uji thitung tersebut lebih besar daripada tabel (2,138> 2,010) dan nilai signifikansi lebih kecil daripada $\alpha=0,05$. Pengujian ini menunjukkan bahwa $\mathrm{H} 0$ ditolak dan $\mathrm{H} 1$ diterima, sehingga dapat disimpulkan bahwa variabel Budaya Organisasi PasifDefensif(X2) berpengaruh signifikan terhadap variabel Kinerja Karyawan (Y).

\section{Variabel Budaya Organisasi Agresif-Defensif (X3)}

Hasil dari pengujian hipotesis koefisien regresi variabel opini (X3) dapat dituliskan Variabel X3 memiliki nilai thitung sebesar 2,953 dan didapatkan nilai signifikansi sebesar 0,005. Nilai statistik uji thitung tersebut lebih besar daripada 
ttabel $(2,953>2,010)$ dan nilai signifikansi lebih kecil daripada $\alpha=0,05$. Pengujian ini menunjukkan bahwa $\mathrm{H} 0$ ditolak dan $\mathrm{H} 1$ diterima, dapat disimpulkan bahwa variabel Budaya Organisasi Agresif-Defensif (X3) berpengaruh signifikan terhadap variabel Kinerja Karyawan (Y).

\section{Deskriptif Budaya Organisasi Terhadap Kinerja Karyawan Budaya Organisasi Konstruktif (X1)}

Berdasarkan dari analisis data deskriptif jawaban responden sebelumnya, diketahui bahwa Budaya Organisasi Konstruktif (X1) pada Bank Rakyat Indonesia Cabang Cianjur memiliki rata-rata keseluruhan (Grand Mean) sebesar 4.15. Pada masing-masing item dan memiliki rata-rata yang baik sehingga mempunyai hasil ratarata keseluruhan sebesar 4.15 yang dapat dikategorikan sebagai angka yang baik sehingga dapat dikatakan Budaya Organisasi Konstruktif berjalan dengan baik pada Bank Rakyat Indonesia Cabang Cianjur

\section{Budaya Organisasi Pasif-Defensif (X2)}

Berdasarkan analisis data deskriptif bahwa data jawaban responden sebelumnya, diketahui Budaya Organisasi Pasif - Defensif pada Bank Rakyat Indonesia Cabang Cianjur memiliki rata-rata keseluruhan sebesar 3.98. Pada masing-masing item tersebut mendapatkan rata-rata yang baik sehingga dapat menghasilkan rata-rata keseluruhan sebesar 3.98 dengan penilaian yang baik sehingga Budaya Organisasi Pasif-Defensif dapat berjalan dengan baik pada Bank Rakyat Indonesia Cabang Cianjur.

\section{Budaya Organisasi Agresif-Defensif (X3)}

Berdasarkan hasil analisis data deskriptif data jawaban responden pada sebelumnya, diketahui bahwa Budaya Organisasi Agresif - Defensif pada Bank Rakyat Indonesia Cabang Cianjur mempunyai rata-rata keseluruhan sebesar 3.93 yang mana pada angka tersebut berasal dari hasil rata-rata setiap item yang berkisar antara 3.67-4.37. Dari angka rata-rata keseluruhan tersebut dengan sebesar 3.93 dinilai baik sehingga Budaya Organisasi Agresif-Defensif dapat berjalan baik pada Bank Rakyat Indonesia Cabang Cianjur.

\section{Kinerja Karyawan (Y)}

Berdasarkan analisis data jawaban deskriptif, data jawaban responden padsebelumnya, diketahui bahwa Kinerja Karyawan padaBank Rakyat Indonesia 
memiliki rata-rata keseluruhan sebesar 4.05 dengan angka tersebut dinilai baik. Karyawan Bank Rakyat Indonesia mempunyaikinerja yang baik dengan diukur dari indikator serta item yang digunakan. Karyawan mampu menyelesaikan tugas-tugas mereka sesuai dengan tugas dan apa yang diperintahkan oleh perusahaan

\section{Pengaruh Budaya Organisasi Konstruktif terhadap Kinerja Karyawan}

Berdasarkan dengan hasil analisis regresi linear Berganda menghasilkan variabel budaya organisasi konstruktif memiliki koefisien regresi sebesar 0.274. Nilai tersebut mempunyai art, variabel bebas budaya organisasi konstruktif mempunyapengaruh positif atau searah dengan kinerja karyawan pada Bank Rakyat Indonesia Cabang Cianjur yaitu ketika budaya organisasi konstruktif mengalami peningkatan sebesar satu satuan, maka kinerja karyawan akan naik sebesar 0.274 satuan dengan asumsi variabel lain konstan. Hasil uji t didapat bahwa variabel bebas budaya organisasi konstruktif berpengaruh signifikansi terhadap kinerja karyawan. Hal ini dengan melihat dari nilai signifikansi yang lebih kecil dari $\alpha$ (alpha) yang dipakai yaitu sebesar 0.05 sehingga $0.020<0.05$. Hasil analisis regresi menunjukkan bahwa variabel budaya organisasi konstruktif yang mempunyai indikator-indikator pencapaian tujuan, aktualisasi diri, dan penghargaan yang manusiawi memiliki pengaruh yang signifikan terhadap kinerja karyawan. Dengan adanya pengaruh yang signifikan tersebut menunjukkan bawah semakin baik perlakuan sebuah perusahaan terhadap penerapan budaya organisasi konstruktif maka akan meingkatkan kinerja karyawan perusahaan itu sendiri. Dalam uji parsial yang dilakukan dapat diketahui variabel mana yang paling dominan berpengaruh terhadap kinerja karyawan. Berdasarkan hasil analisis yang dilihat dari koefisien regresi dapat diketahui bahwa koefisien variabel budaya organisasi konstruktif sebesar 0.020 , koefisien regresi variabel budaya organisasi pasif-defensif sebesar 0.038 dan koefisien variabel budaya organisasi agresif- defensif sebesar 0.005. Berdasarkan dari hasil analisis tersebut dapat disimpulkan bahwa budaya organisasi konstruktif berpengaruh terhadap kinerja karyawan Bank Rakyat Indonesia Cabang Cianjur. Rata-rata karyawan Bank Rakyat Indonesia Cabang Cianjur menunjukkan nilai sebensar 4.15. Dengan hal tersebut, sehingga menunjukkan bahwa tanggapan setiap karyawan terhadap budaya organisasi konstruktif adalah baik. Kinerja setiap karyawan dapat dipengaruhi secara signifikan oleh budaya organisasi konstruktif dengan cara penerapan budaya organisasi konstruktif yang sesuai dengan harapan sehingga mampu meningkatkan kinerja karyawan. 
Berdasarkan hasil analisis regresi linear berganda dengan mendapatkan variabel budaya organisasi pasif-defensif memiliki koefisien regresi sebesar 0.621. Nilai tersebut mempunyai arti bahwa variabel bebas budaya organisasi pasif-defensif memiliki pengaruh positif atau searah terhadap kinerja seorang karyawan yaitu ketika budaya organisasi pasif defensif meningkat sebensar 0.621 satuan maka kinerja karyawan juga akan meningkat sebesar 0.621 satuan dengan asumsi variabel lain konstan. Hasil uji t didapat bahwa variabel budaya organisasi pasif defensif berpengaruh signifikan terhadap kinerja karyawan. Hal ini dapat dilihat dari nilai signifikansi yang lebih kecil dari $\alpha$ (alpha) yang dipakai yaitu sebesar 0.05, sehingga $0.038<0.052$. Hasil analisis regresi tersebut menunjukkan bahwa budaya organisasi pasif-defensif memiliki pengaruh signifikan terhadap kinerja karyawan. Hal tersebut menunjukkan bahwa dengan melakukan pekerjaan secara konsevatif, jajaran perusahaan yang dilakukan oleh pimpinan, pengambilan keputusan secara sentral, dan pelibatan seorang karyawan dalam pengambilan keputusan akan memberikan pengaruh positif terhadap kinerja karyawan. Apabila variabel budaya organisasi pasif-defensif lebih dimaksimalkan maka kinerja karyawan juga akan meningkat. Jika karyawan bekerja sudah sesuai dengan standar prosedur operasional yang harus dilakukan maka kinerja karyawan akan meningkat. Hal ini ditunjukkan dari tanggapan karyawan Bank Rakyat Indonesia Cabang Cianjur tentang budaya organisasi pasif- defensif dengan rata-rata 3.98 yang berarti budaya organisasi pasif-defensif pada perusahaan tersebut cukup baik. Berdasarkan hasil penelitian menunjukkan bahwa ketika seorang karyawan cukup nyaman bekerja dengan aman maka kinerja karyawan akan tetap terjaga.

\section{Pengaruh Budaya Organisasi Agresif-Defensif terhadap Kinerja Karyawan}

Berdasarkan hasil dari analisis regresi linear berganda didapat variabel budaya organisasi agresif-defensif memiliki koefisien regresi sebesar 0.462. Nilai tersebut menunjukan bahwa variabel budaya organisasi agresif-defensif berpengaruh positif atau searah terhadap kinerja karyawan berarti jika variabel budaya organisasi agresifdefensif meningkat sebesar 0.462 satuan, maka kinerja karyawan juga akan mengalami peningkatan sebesar 0.462 satuan dengan asumsi variabel lain konstan. Hasil uji t menunjukkan variabel budaya organisasi agresif-defensif berpengaruh signifikan terhadap kinerja karyawan. Hal ini dapat dilihat dari nilai signifikansi yang lebih kecil dari $\alpha$ (alpha) yang dipakai yaitu sebesar 0.05 sehingga $0.005<0.05$. Hasil analisis regresi tersebut menunjukkan bahwa budaya organisasi agresif- defensif merupakan salah satu faktor yang berpengaruh signifikan terhadap kinerja seorang karyawan. Hal 
itu menunjukkan bahwa dengan menerapkan sikap kritis, penentangan ide untuk mencari memecahkan ide yang terbaik, penggunaan kekuasaan yang sesuai, tidak bersikap semena-mena, persaingan antar karyawan, adanya suatu anggapan bahwa bekerja merupakan berkompetisi maka dapat meningkatkan kinerja karyawan. Hal ini berasal dari tanggapan karyawan Bank Rakyat Indonesia Cabang Cianjur tentang budaya organisasi agresif-defensif dengan rata-rata besar 3.93 yang berarti budaya organisasi agresif-defensif dalam perusahaan berjalan dengan baik.

\section{Pengaruh secara Simultan Budaya Organisasi Konstruktif, Budaya Organisasi Pasif-Defensif dan Budaya Organisasi Agresif-Defensif terhadap Kinerja Karyawan}

Berdasarkan dari analisis regresi simultan yang digunakan dapat menjawab sebuah hipotesis yang menyatakan "Apakah budaya organisasi konstuktif, budaya organisasi pasif-defensif, dan budaya organisasi agresif-defensif berpengaruh simultan terhadap kinerja karyawan?" dalam penelitian ini menunjukan variabel budaya organisasi konstruktif, budaya organisasi pasif- defensif, dan budaya organisasi agresif-defensif berpengaruh simultan terhadap kinerja karyawan. Hal ini dibuktikan dengan Fhitung > Ftabel $(21.680>2.794)$. Hasil dari Adjust $R$ Square yaitu sebesar 0.545 yang artinya variabel-variabel bebas berpengaruh sebesar $54.5 \%$ terhadap kinerja seorang karyawan dan sisanya $45.6 \%$ dipengaruhi oleh faktor-faktor lain yang tidak dibahas dalam penelitian ini. Jadi kesimpilan yang dapat diambil bahwa budaya organisasi konstruktif suatu perusahaan, budaya organisasi pasif-defensif, dan budaya organisasi agresifdefensif mempunyai keterikatan dan pengaruh terhadap kinerja karyawan. Hasil dari penelitian ini menunjukkan pengaruh yang signifikan dengan menunjukkan bahwa perusahaan tersebut telah memberikan sesuai dengan indikator-indikator yang peneliti gunakan dalam penelitian ini, dan selama perusahaan mampu memaksimalkan dan meningkatkan budaya organisasinya maka kinerja karyawan akan meningkat.

\section{KESIMPULAN}

Terdapat pengaruh yang signifikan yang berasal dari Budaya Organisasi Konstruktif terhadap Kinerja Karyawan Bank BRI Kantor Cabang Cianjur. Terdapat pengaruh yang signifikan dari Budaya Organisasi Pasif-Defensif terhadap Kinerja Karyawan Bank BRI Kantor Cabang Cianjur. Terdapat pengaruh yang signifikan dari Budaya Organisasi Agresif-Defensif perusahaan terhadap Kinerja Karyawan Bank BRI Kantor Cabang Cianjur.

Terdapat pengaruh yang signifikan secara simultan antara Budaya Organisasi 
Konstruktif, Budaya Organisasi Pasif- Defensif, dan Budaya Organisasi AgresifDefensif terhadap Kinerja Karyawan Bank BRI Kantor Cabang Cianjur.

Hasil penelitian ini dapat membuktikan bahwa budaya organisasi konstruktif suatu perusahaan dapat berpengaruh positif terhadap kinerja karyawan. Perusahaan diharapkan untuk terus meningkatkan dan menyempurnakan budayanya agar kinerja karyawan dapat lebih meningkat dan dapat mencapai tujuan dari perusahaan.

Hasil penelitian membuktikan bahwa budaya organisasi pasif-defensif berpengaruh positif terhadap kinerja karyawan di perusahaan. Untuk meningkatkan kinerja karyawan maka perlu melakukan pemanfaatan dan memaksimalkan unsurunsur budaya organisasi sehingga kinerja karyawan dapat lebih meningkat.

Hasil penelitian membuktikan bahwa budaya organisasi agresif-defensif berpengaruh positif terhadap kinerja karyawan. Untuk meningkatkan kinerja karyawan di perusahaan maka perusahaan harus lebih memperhatikan budaya organisasi dengan melihat dari indikator-indikator yang ada maka perusahaan perlu meningkatkan community sharing atau diskusi antar karyawan mengenai tugas dan kewajiban yang harus dilaukan untuk mencapai sebuah tujuan bersama, serta perusahaan harus selalu mengawasi tingkah laku karyawan agar tidak berbuat hal-hal yang akan menghambat tujuan perusahaan. Hal tersebut jika dapat diterapkan oleh perusahaan maka dapat meningkatkan kinerja karyawan itu sendiri.

\section{DAFTAR PUSTAKA}

Sutarto, 2006. Dasar-dasar Organisasi. Yogyakarta: Gadjah Mada University Press.

Sutrisno, Edi. 2013. Budaya Organisasi. Jakarta : Kencana

Wibowo. 2007. Manajemen Kinerja. Jakarta: Rajawali Pers

Wirawan. 2009. Evaluasi Kinerja Sumber Daya Manusia. Jakarta: Salemba Empat.

Mangkunegara, Anwar. 2005. Manajemen Sumber Daya Manusia Perusahaan. Jakarta : Salemba Empat.

Miller, Lawrence M. 1984. Manajemen Era Baru: Beberapa Pandangan Mengenai Budaya Perusahaan Modern. Jakarta : Penerbit Erlangga

Hasibuan, H. Malayu S.P. 2005. Manajemen Sumber Daya Manusia. Yogyakarta : BPFE-UGM.

Hessel, Nogi S.Tangkilisan. 2007. Manajemen Publik. Jakarta: Grasindo

Kreitner, Robert dan Kinicki, Angelo. 2005. Perilaku Organisasi. Edisi Pertama. Buku 1. Jakarta: Salemba Empat. 
Hasibuan, H. Malayu S.P. 2005. Manajemen Sumber Daya Manusia. Yogyakarta : BPFE-UGM.

Hessel, Nogi S.Tangkilisan. 2007. Manajemen Publik. Jakarta: Grasindo

Kreitner, Robert dan Kinicki, Angelo. 2005. Perilaku Organisasi. Edisi Pertama. Buku 1. Jakarta: Salemba Empat.

Mulyadi Deddy, Rivai Veithzal. 2006. Kepemimpinan dan Perilaku organisasi. Jakarta: Rajawali Pers.

Nurdin Ismail. 2012. Budaya Organisasi: konsep, teori, dan implementasi. Malang. UB Press.

Pabundu Tika. 2010. Budaya Organisasi dan Peningkatan Kinerja Karyawan. Jakarta: Bumi Aksara.

Robbins, Stephen P. 2006. Perilaku Organisasi, Jakarta: Gramedia. 